$\begin{array}{ll} & \text { Etnográfica } \\ \text { etnográfica } & \text { Revista do Centro em Rede de Investigação em }\end{array}$

Antropologia

vol. $17(2) \mid 2013$

Vol. $17(2)$

\title{
Vidas experimentais: humanos e roedores no laboratório
}

Experimental lives: humans and rodents in the lab

\author{
lara Maria de Almeida Souza
}

\section{(2) OpenEdition}

Journals

Edição electrónica

URL: https://journals.openedition.org/etnografica/3108

DOI: 10.4000/etnografica.3108

ISSN: 2182-2891

\section{Editora}

Centro em Rede de Investigação em Antropologia

\section{Edição impressa}

Data de publição: 1 junho 2013

Paginação: 241-268

ISSN: 0873-6561

\section{Refêrencia eletrónica}

lara Maria de Almeida Souza, «Vidas experimentais: humanos e roedores no laboratório», Etnográfica [Online], vol. 17 (2) | 2013, posto online no dia 19 junho 2013, consultado o 09 fevereiro 2022. URL: http://journals.openedition.org/etnografica/3108 ; DOI: https://doi.org/10.4000/etnografica.3108

\section{(c) (7) \&}

Etnográfica is licensed under a Creative Commons Attribution-NonCommercial 4.0 International License. 


\section{Vidas experimentais: humanos e roedores no laboratório}

\section{Iara Maria de Almeida Souza}

O renovado interesse despertado pelo estudo das relações entre humanos e animais na antropologia envolve uma consideração sobre os modos como a vida e a morte de vários organismos vivos estão ligadas aos mundos sociais humanos, ou seja, o mundo comum é visto como um campo de relações mais amplo, povoado por uma miríade de seres com os quais os humanos se enredam. Em sintonia com as questões trazidas por esta literatura, a interrogação que conduz a discussão a seguir é: como pensar, a partir desta abordagem, as relações entre os pesquisadores e os roedores no laboratório, quando sabemos que estas são caracterizadas, de modo assertivo e direto, como meramente instrumentais? Neste artigo exploramos, a partir de investigação realizada em um laboratório e biotério pertencentes a uma instituição pública brasileira, qual o sentido prático da instrumentalidade neste contexto (os procedimentos formalizados para lidar com os animais, a produção de um modelo animal de doença, o aparato instrumental no qual os roedores estão inseridos), os modos de resposta dos animais e a existência de relações irredutíveis à objetificação entre os pesquisadores e os roedores.

PALAVRAS-CHAVE: modelo animal, etnografia multiespécie, biotecnologia, biotério, dispositivo experimental, roedores.

Experimental lives: humans and rodents in the lab - Anthropology's renewed interest in the study of human-animal relations leads to considerations regarding the ways in which the life and death of various living organisms are connected to human worlds. This implies a definition of the common world as a wider field of relations, inhabited by a myriad of beings with which humans are enmeshed. Closely in tune with the questions raised by the anthropological literature on human-animal relations, the question that guides the following discussion is how to think, on the basis of this approach, relations between researchers and mice in the laboratory, when we know that these relations are characterized in a very assertive and outright manner as merely instrumental. Based on fieldwork carried out in the laboratory of a Brazilian public institution for scientific research, the article explores the practical meaning of instrumentality in this context (the formal procedures for dealing with animals, the production of an animal model of disease, the instrumental apparatus in which the rodents are inserted). It also addresses the animals' modes of answering to the experimental context and points to the existence of relations between researchers and rodents that are irreducible to objectification.

KEYWORDS: animal model, multispecies ethnography, biotechnology, experimental systems, bioterium, rodents.

SOUZA, Iara Maria de Almeida (imas@ufba.br) - Programa de Pós-Graduação em Ciências Sociais, Universidade Federal da Bahia, Brasil. 


\section{AS RELAÇÕES ENTRE HUMANOS E ANIMAIS SE CONVERTERAM NOS} últimos anos em um tópico de crescente interesse na antropologia. ${ }^{1}$ Tal temática não é propriamente uma descoberta recente na disciplina. De início - quando boa parte da pesquisa antropológica era conduzida entre povos que viviam da caça ou pastoreio - os animais já se faziam notar. A atenção concedida a eles, entretanto, se limitava fundamentalmente aos aspectos instrumentais das relações que entretinham com os humanos. Ou seja, os animais interessavam apenas na medida em que eram caracterizados como "bons para comer". Posteriormente, a crítica ao reducionismo utilitarista retirou-os da dura prisão da materialidade e os conduziu ao terreno do simbólico; eles se tornaram então "bons para pensar" (Mullin 1999). Embora divergentes, em nenhuma das abordagens se demonstrava qualquer interesse pelos animais propriamente ditos; estes eram vistos como objetos passivos frente às ações e intenções humanas (Knight 2005). É justamente este ponto que a literatura atual pretende subverter, ao mostrar os animais como entidades ativas e participantes de pleno direito nas sociedades humanas. Os modos como a vida e a morte de vários organismos vivos estão ligadas aos mundos sociais humanos constituem o cerne das etnografias multiespécies (Kirksey e Helmreich 2010). Um projeto bastante próximo ao que Eduardo Kohn (2007) chama de antropologia da vida: "uma antropologia que não é confinada apenas ao humano, mas que se interessa pelos efeitos de nosso entrelaçamento com outros tipos de seres vivos" (Kohn 2007: 3). Quer seja na observação de práticas de caça, de pastoreio ou dos vínculos estabelecidos com animais de estimação, estudos mostram que a existência de relações com animais envolve bem mais do que representações sociais ou a existência de laços puramente instrumentais (Knight 2005; Holmberg 2011 ; Despret 2008).

Ao rejeitar simultaneamente a concepção intelectualista - em que o animal é interpretado como símbolo ou representação - e a utilitarista - que privilegia a instrumentalidade -, este novo modo de abordar as relações entre humanos e animais recusa também o antropocentrismo inerente às duas concepções e pretende fazer jus ao fato de que vivemos em um mundo comum, mais amplo, povoado por uma miríade de seres com os quais os humanos se enredam. Uma das implicações disso é que a própria definição de humano não pode mais ser pensada em termos de uma essência atemporal, constituída prévia e independentemente das conexões estabelecidas com outros seres vivos ou espécies companheiras, para usar o termo de Haraway (201 l).

Em sintonia com as questões trazidas por esta literatura, a interrogação que conduz a discussão a seguir é: como pensar, a partir desta abordagem, as relações entre os pesquisadores e os seus animais de laboratório, quando sabemos 
que estas são caracterizadas, de modo assertivo e direto, como meramente instrumentais? Ora, rejeitar a concepção utilitarista como ponto de partida não implica em abandonar o interesse por todo e qualquer contexto de prática em que pareçam predominar as relações instrumentais com animais; ao invés disso, a observação deste tipo de ambiente incita (ou ao menos deveria incitar) a curiosidade por explorar, em outra chave, o sentido prático do instrumental e a existência de diferentes vínculos entre humanos e animais irredutíveis à mera instrumentalidade.

Para introduzir as questões a serem discutidas adiante neste texto, apresento uma breve conversa, sobre o tema das relações entre pesquisadores e animais, que tive com cientistas - dr. ${ }^{\text {a }}$ Débora, dr. ${ }^{a}$ Sara e dr. ${ }^{a}$ Beatriz - que trabalham em uma grande instituição de pesquisa:

"Eu: Estou pensando em fazer uma pesquisa sobre a relação entre pesquisadores e animais aqui no biotério, o que vocês acham?

Dr. ${ }^{a}$ Débora: Essa pesquisa não vai levar a nada, não há o que dizer sobre isso, os animais são como coisas, são apenas instrumentos de pesquisa como outros.

Eu: Mas há estudos sobre a relação entre humanos e animais mostrando que, além das relações instrumentais, há possibilidades de formação de outros tipos de vínculos com os animais e eu quero saber se isso acontece na prática, no biotério.

Dr. ${ }^{a}$ Débora: Os animais são gêmeos idênticos, não se pode distinguir um do outro, como pode haver vínculo?

Dr. ${ }^{a}$ Sara: Eu discordo de Débora, posso dar o meu exemplo. Em meu mestrado e no doutorado, usei muitos animais na pesquisa sem qualquer problema, mas depois que passei a criar uma gata em casa, comecei a olhar de outro modo os camundongos e a reconhecer os sentimentos deles. Por isso, nunca mais tive coragem de sacrificar animais.

Dr. ${ }^{a}$ Beatriz: Desde a faculdade nunca suportei sacrificar animal, por isso logo cedo escolhi não fazer pesquisas em que eu precisasse usar animais.

Dr. ${ }^{a}$ Débora: É, talvez você [se dirigindo a mim] possa encontrar alguma coisa. Eu vejo que as estudantes da área de veterinária sempre olham para o animal e dizem, "hoje ele está com uma carinha boa" ou "ele está um pouco tristinho". [...] Atualmente eu não vou mais ao biotério e não manuseio animais, meus estudantes cuidam desse trabalho. Mas lembro que quando minha filha nasceu, eu trabalhava em uma pesquisa em que era necessário sacrificar muitos animais. À noite quando voltava para casa e via minha filhinha dormindo, parecia que eu estava vendo um camundongo, eu tentava afastar essa visão, mas a imagem do camundongo sempre voltava." 
Iniciei a apresentação do meu campo de interesse mais específico com esta breve conversação porque nela já se insinuam os temas a serem explorados: o animal como "coisa", a sua homogeneidade genética, o sacrifício, sua face, a proximidade e a distância com relação a outros animais e aos humanos. A conversa também indica que a atribuição do rótulo de instrumental a toda e qualquer relação entre humanos e roedores na pesquisa não esgota tudo o que há a dizer sobre o tema. Além disso, a questão não se resume a reconhecer a existência de outro tipo de vínculo entre pessoas e animais no ambiente do biotério. É preciso também qualificar melhor o que é a instrumentalidade. Quais são os procedimentos formalizados para lidar com os animais? Como converter um animal em um modelo de doença? Como os animais respondem? São algumas dessas questões que pretendo explorar brevemente neste artigo, que, mais do que fornecer uma resposta definitiva sobre o tema, pretende abrir a imaginação a uma série de novas perguntas possíveis sobre os entrelaçamentos das vidas de humanos e animais na ciência.

O material empírico apresentado aqui foi obtido em pesquisa realizada (entre 2008 e 2009) em uma grande instituição pública brasileira, voltada para a pesquisa biomédica, com atuação principalmente no estudo de doenças infecciosas e parasitárias. O instituto conta com dez laboratórios e um biotério e abriga dois cursos de pós-graduação conveniados a uma universidade também pública. As entrevistas e observações apresentadas foram coletadas, em sua maior parte, no âmbito de um único laboratório, para uma investigação que visava acompanhar o desenvolvimento de terapias com células-tronco (ou células estaminais). Foi durante o desenvolvimento desta pesquisa que os camundongos - os animais mais utilizados nas pesquisas que acompanhei começaram a se mostrar mais complexos e recalcitrantes do que eu seria capaz de conceber e, por fim, em um novo projeto de investigação, vieram a se tornar o centro das atenções.

\section{ANIMAIS E ANTROPOLOGIA}

Não é possível dizer que autores clássicos da antropologia tenham deixado de reconhecer a presença de animais ao estudarem diferentes povos que, em grande parte, viviam de caça e pastoreio. Evans-Pritchard não faz menção ao gado (2007) e a galinhas (1978)? E os galos não são comentados por Geertz (1978)? Lévi-Strauss, por sua vez, não cita várias espécies ao falar dos animais que simbolizam clãs, como o pato, a águia, o grou, a lontra, o castor, etc. (1975)? É desnecessário prosseguir arrolando os animais que aparecem em uma vasta série de trabalhos antropológicos; também não cabe tentar condensar em poucas linhas as variações nos modos de retratá-los. O ponto mais importante do argumento é: quando os animais aparecem em cena nestes estudos, usualmente, desempenham o papel de meros intermediários na análise 
dos tópicos considerados realmente relevantes para a antropologia, a saber, o estudo de formações sociais específicas e das relações dos humanos com outros humanos. De acordo com Mullin (1999), as diferentes interpretações das relações entre humanos e animais não humanos tendiam a oscilar entre dois polos, ou tomavam a forma de explicação utilitarista e econômica, como a análise feita por Harris (1974, apud Mullin 1999) acerca da sacralidade do gado na Índia, ou, inversamente, se adotava uma perspectiva estruturalista/simbólica, segundo a qual seria um equívoco explicar o uso de animais totêmicos por seu valor econômico. Para Lévi-Strauss, por exemplo, a eleição de determinados animais como totens não se dava porque eram "bons para comer", mas, ao contrário, porque eram "bons para pensar", pois as distinções observáveis entre as espécies ofereciam um recurso conceitual para a diferenciação social (1975: 94). Ainda segundo Mullin (1999), não foram raras as tentativas de mesclar as dimensões materiais e simbólicas para pensar a presença dos animais nas sociedades humanas. Em qualquer caso, os animais são retratados como seres destituídos de interesse, pois não possuem capacidade de ação e resposta; eles entram na vida social apenas para serem submetidos às necessidades materiais ou simbólicas dos humanos (Mullin 1999).

Este modo de pensar não revela apenas o antropocentrismo, ou seja, uma concepção do "excepcionalismo da espécie" (Haraway 2011) na qual se fundamenta, mas deixa entrever também o pressuposto - nem sempre explicitado de que a realidade é constituída por dois domínios ontologicamente distintos: a natureza e a cultura. A excepcionalidade do humano residiria justamente em sua capacidade de transcender o domínio da natureza e construir cultura(s). Desta esfera, os animais só podem participar como recurso material ou simbólico.

Não são poucos os autores a apontar para as dificuldades inerentes a esta dicotomia. Não é o caso aqui de retomarmos todos os argumentos apresentados. Tendo em conta os propósitos deste artigo, vou evocar apenas uma vertente importante da crítica à oposição entre natureza e cultura trazida por antropólogos que estudam povos caçadores e coletores, em especial Ingold (2000). Ao contrastar as formas distintas de os humanos se relacionarem com os animais nos regimes de caça e de pastoreio, Ingold conta uma história alternativa à narrativa usual - que avalia como uma evolução cultural a transição da atividade de caça para a de domesticação de animais - ao mesmo tempo em que põe em questão a própria divisão entre natureza e cultura.

Segundo Ingold (2000), para caçadores-coletores o ambiente é vivo, saturado de poderes pessoais. Os caçadores só podem sobreviver se mantiverem relações de reciprocidade com esses poderes, similares àquelas que estabelecem com outras pessoas. Em seu mundo os animais são seres responsivos e, por conseguinte, devem ser tratados com respeito e consideração. Não há, neste caso, uma separação entre natureza e cultura, mas se vive em um mundo 
comum habitado por diferentes entidades dotadas de poderes pessoais. Com a domesticação, os animais perdem justamente a capacidade de responder e agir de modo recíproco. É o pastor quem decide sobre sua vida, sua morte e provê as condições de seu bem-estar. Além disso, eles são convertidos em propriedade, coisas que podem ser possuídas, herdadas, comercializadas. Diferente do regime de caça, em que a relação entre humanos e animais se caracteriza pela confiança, o regime de pastoreio se funda em uma relação de dominação, levada ao extremo na forma de criação industrial de animais (Ingold 2000). Sem dúvida, a criação de animais em biotérios e sua utilização em pesquisas científicas se enquadrariam à perfeição na descrição de Ingold do regime de domesticação/dominação mais radical. O nascimento, vida e morte destes animais é, ao menos assim se pretende, completamente controlado. O que pode haver no biotério, além de dominação? Poderiam os animais responder neste contexto? Se nos fiarmos apenas em Ingold, me parece que a resposta a ambas as perguntas seria negativa.

Knight (2005), contudo, sugere que sejamos mais prudentes ao negar a existência de relações responsivas em contextos de domesticação. Além disso, ele põe em dúvida a concepção de Ingold de que na caça, tal qual praticada por povos caçadores e coletores, o caçador efetivamente mantém com os animais relações semelhantes àquelas que ele estabelece com pessoas. Segundo Knight, o caçador jamais pode conviver com o animal com o mesmo grau de familiaridade que é possível alcançar em um contexto de domesticação. Essa convivência mais constante e durável não poderia favorecer ou levar ao surgimento de relações de intimidade e ao reconhecimento de alguma responsividade da parte do animal? Knight argumenta que sim, mas, para que possamos reconhecer os traços de pessoalidade em relações de subordinação, é necessário não confundir o resultado (animais instrumentalizados, explorados como fonte de alimento e trabalho) com o processo. A preocupação com os resultados talvez esconda uma relação de cuidado na qual o animal não pode ser reduzido a objeto.

A atenção ao processo - pensado em termos de uma narrativa etnográfica é justamente aquilo que falta, em grande medida, à discussão sobre a presença de animais na ciência. À exceção dos estudos sobre primatologia, a antropologia da ciência pouco tem se ocupado daquilo que é próprio à interação entre os pesquisadores e os animais que são objeto de sua atenção. E a menção à primatologia não é casual, pois esta disciplina desafia vários dos pressupostos objetivistas acerca de como as interações em campo devem ser conduzidas (Rees 2007; Sá 2010).

Não é que os antropólogos da ciência tenham ignorado o uso do modelo animal em pesquisa ou negligenciado o fato, apontado por Landecker (2007), de que o uso de material biológico humano constitui apenas uma fração mínima em um vasto conjunto que engloba materiais de diferentes espécies. Contudo, no caso específico, eles se mostram mais atentos às consequências do 
que aos processos, ou seja, eles se interessam mais pelo tipo de conhecimento que se obtém com o uso de animais do que propriamente pelos animais e suas relações com os humanos (Davies 2010; Fujimura 1996; Logan 2001; Birke 2003). Identificamos tal atitude mesmo no artigo seminal de cunho etnográfico, escrito por Lynch (1988), cujo interesse principal é mostrar como o animal vivo, "natural", é ritualmente transformado em animal "analítico".

De fato, deveríamos esperar precisamente o oposto dos estudos de ciência, em especial as etnografias de laboratório; afinal, tais estudos foram responsáveis em grande medida pela renovação da discussão acerca de agência, ao incluir no rol de atores relevantes para as práticas sociais (quaisquer que sejam, não apenas as científicas) atores não humanos. A despeito da existência de discordâncias teóricas, tais estudos convergiam, ao mostrar que a ciência não é feita apenas de padrões de carreira e reconhecimento, habitus, lutas pelo poder e acordos entre cientistas, mas que sua prática envolve a associação de entidades heterogêneas, humanas e não humanas, compreendendo substâncias, equipamentos, animais, coisas que são convocadas a participar da ciência, são submetidas a provas e podem falhar, atuar de modo diverso do esperado, bem como sugerir e abrir novas questões de investigação (Stengers 2002; Knorr-Cetina 1983, 1999; Latour 1999; Pickering 1995). Esta abordagem afirma a existência de coisas que são simultaneamente materiais e significativas; possuem plasticidade, mas também constrangem e limitam as práticas; têm forças, trajetórias, tendências, propensões, recalcitrância, e trazem uma margem de indeterminação que não nos permite fixar de antemão tudo que podemos esperar delas.

Sendo assim, como compreender por que os animais, que possuem força, trajetória, recalcitrância, demoram a receber atenção nos estudos de ciência? Talvez o fato de que, no presente, o uso do modelo animal em ciências biomédicas seja algo bastante estabilizado e não controverso (principalmente ao interior do laboratório, pois a controvérsia ética e a disputa acerca de legislação que regulamente o uso de animais em pesquisa não parece dar sinais de estabilização) explique a relativamente escassa atenção que estas criaturas receberam nas etnografias de laboratório, usualmente mais centradas em seguir as trajetórias de coisas controversas, em torno das quais a caixa preta ainda não se fechou, ou seja, "coisas epistêmicas", entidades situadas no cerne do processo de pesquisa e a meio caminho de sua definição material, ao invés de atentar para os "objetos tecnológicos", aqueles já fixados, não problemáticos, transformados em recurso sempre à mão do pesquisador (Rheinberger 1997).

O interesse mais específico pelos componentes vivos do laboratório ganhou mais importância em estudos de história da ciência. Na história das ciências, entidades vivas, como moscas, vírus, vermes ou camundongos, despontaram como objeto de interesse em estudos que recuperam os caminhos sempre contingentes através dos quais estas entidades foram erigidas como organismos 
preferenciais em determinadas áreas de pesquisa (Creager 2002; Logan 2001; Rader 2004; Kohler 1994). A despeito da visibilidade alcançada pelos organismos vivos em tais narrativas, talvez por conta de dificuldades inerentes às suas fontes históricas, são parcos os relatos sobre como se dá a interação entre os humanos e outras espécies, sobre as práticas de cuidado e ordenamento dos animais e sobre como eles respondem à situação. Exceção são os estudos conduzidos por Holmberg (2011) - sobre aprendizado de cuidados e manejo de animais de pesquisa - e por Sá, Medeiros e Schirmann (201 l) - sobre práticas relativas ao uso de modelos animais em um laboratório de neurotoxicidade e psicofarmacologia. Adiante voltaremos a esta literatura, em um diálogo mais direto com os achados empíricos que apresentaremos a seguir.

\section{"CAMUNDONGOS SÃO COMO SUBSTÂNCIAS QUÍMICAS"}

Embora os camundongos, bem como os humanos que interagem com eles no laboratório ou biotério, sejam o foco deste artigo, inicio esta secção apresentando alguns fragmentos de uma entrevista realizada em outro lugar que não o biotério, uma sala de um hospital de veterinária. Aí trabalha uma pesquisadora, a dr. ${ }^{a}$ Tereza, responsável pela condução de um ensaio clínico com células-tronco, cujo efeito foi a recuperação dos movimentos de um gato com lesão da coluna vertebral. O resultado obtido com o experimento foi noticiado com destaque no telejornal local. Na matéria veiculada na televisão foram exibidas imagens de um gato apresentando uma marcha difícil, quase rastejante, mas ainda assim o resultado foi um feito extraordinário, se considerarmos que antes do tratamento o animal estava completamente paralisado. Logo após a exibição da notícia na TV, os responsáveis pelo ensaio clínico foram surpreendidos por uma profusão de telefonemas e $e$-mails. Entre aqueles que os procuravam havia quem desejasse oferecer seu animal de estimação - padecendo de alguma doença - para os experimentos com células-tronco, mas havia também um número considerável de humanos aspirando para si o papel de "cobaia" nos experimentos. Seu argumento era que os médicos recusavam-se a utilizar em humanos os tratamentos que estavam sendo testados em animais e assim retiravam deles a chance de gozar dos mesmos benefícios obtidos por estes últimos. Tal revindicação se fazia cega à principal justificativa ética para a utilização de animais em pesquisa: cabe a eles o ônus do risco no desenvolvimento de técnicas e produtos que servirão, se este for o caso, posteriormente aos humanos. Com efeito, a exigência de testar primeiro em animais (também in vitro ou em outros modelos de simulação) os novos tratamentos ou drogas, ao invés de experimentá-los diretamente em humanos, resultou de um processo político em que se buscava defender os sujeitos de pesquisa - é assim que são chamadas as pessoas que participam de ensaios clínicos - dos riscos trazidos por intervenções que podem resultar simplesmente ineficazes, mas boa 
parte das vezes, mesmo quando produzem efeitos positivos, causam também danos, alguns dos quais severos e irreversíveis (Pignarre 2004). As pessoas que revindicavam o lugar de cobaia, atraídas pela promessa laica de salvação nesta vida fortemente associada a terapias com células-tronco (Souza 2011), não divisavam o pesado ônus suportado pelos animais no desenvolvimento de um novo tratamento e almejavam o privilégio de serem os primeiros a se beneficiar com os resultados dos testes clínicos.

O ensaio clínico mencionado acima foi fruto da parceria entre um laboratório que desenvolve pesquisas com células-tronco e uma equipe do hospital universitário de medicina veterinária, da qual fazia parte a dr. ${ }^{a}$ Tereza. Seu interesse de pesquisa não era originalmente as células-tronco, mas a leishmaniose, uma enfermidade da qual padecem tanto humanos quanto animais. $\mathrm{O}$ desenvolvimento da investigação sobre essa doença demandou a realização de um extenso trabalho de campo, com visitas a comunidades com altos índices de prevalência de leishmaniose na busca por cães infectados. Em sua tese, a dr. ${ }^{a}$ Tereza defendia a hipótese de que a política de recolhimento e sacrifício de cães contaminados não era a melhor solução para conter a infecção. Segundo ela, assim que um cão de estimação era retirado de uma casa, o dono do animal recolhido logo trazia outro para ocupar o lugar do antigo. Usualmente, este novo cão era um filhote cujo sistema imunológico possuía menos defesas e tendia, por isso, a se contaminar e desenvolver a doença de modo mais rápido e severo. Sendo assim, argumenta ela, seria mais adequado manter um cão adulto com níveis baixos de infecção - que contamina menos - do que promover uma situação em que o animal é substituído por outro com menos defesas imunológicas.

A procura dos animais tornou sua pesquisa mais árdua e lenta. Colegas aconselharam-na a abreviar o esforço, infectando cães para obter rapidamente a quantidade necessária de animais doentes. Embora a dr. ${ }^{a}$ Tereza - crítica da política de sacrificar cães contaminados indiscriminadamente - soubesse que tal estratégia é utilizada com frequência para reduzir custos e a duração da pesquisa, se recusou a fazê-lo porque, em sua concepção, cães são animais sensíveis e inteligentes, por isso não podem ser tratados como animais de laboratório.

Mas o que é então um animal de laboratório? Vejamos o que ela diz:

“Tereza: Surgiu a ideia de fazer o mesmo [transplante de células-tronco] em animais de estimação, que é completamente diferente de animal experimental, né? O rato, o camundongo, eles fazem lá o experimento, o animal é usado como se fosse um material qualquer, né? É descartado, morre. O animal de companhia, não, é como se fosse um ser humano, sem as restrições legais que existem atualmente p'ra pesquisa com seres humanos." 
Apesar de dizer, em um tom que soou como uma censura, que os animais de laboratório são tratados como coisas e descartados, ela não é contra o uso de roedores em laboratório:

“Tereza: A depender da pesquisa, o camundongo é necessário... Por exemplo, você quer avaliar um aspecto da resposta imunológica, tem que avaliar só aquela célula, aquela molécula, então é claro que se houver camundongos de diferentes linhagens, complica. Ou tem coisas que requerem uma igualdade genética, ou seja, se fazendo o cruzamento de irmão com irmão, com irmão, até que todos fiquem geneticamente idênticos, né? [...] Tem que ter igualdade genética para que na hora em que você interferir p'ra modificar aquela molécula, p'ra ver o que acontece, todos têm que responder igual e tem que ter um número estatisticamente significativo [...], mas não se pode extrapolar isso p'ra o estudo clínico, o estudo clínico é feito numa população absolutamente heterogênea. [...] Eu não concordo muito também não [com o uso de roedores], mas ainda não se vislumbra uma forma que substitua cem por cento isso. Agora, o cão, é claro, é muito mais inteligente que o camundongo, nele é mais desenvolvida a perspicácia, a capacidade de sentir e de interação emocional com o ser humano."

$\mathrm{O}$ argumento de Tereza se alinha com uma concepção bastante presente desde os primórdios da luta em defesa do antivivisseccionismo, segundo a qual os homens têm obrigações diferenciadas para com os cães, pois estes são animais sensíveis que vivem em consórcio íntimo com os humanos e, por conseguinte, devem ser tratados com afeto e altruísmo (Lederer 1992). Para a dr. ${ }^{\mathrm{a}}$ Tereza, além disso, há certas qualidades que os humanos possuem das quais os animais podem ser dotados em maior ou menor proporção: inteligência, sensibilidade e capacidade de interação emocional. Os cães estão mais próximos dos humanos que os camundongos e ratos, por isso estes últimos podem servir aos experimentos. Sua fala também está em sintonia com a justificativa apresentada por vários cientistas para a utilização de modelos animais em pesquisa - eles compreendem que há um sofrimento dos animais, contudo não divisam um modo de substituir por completo os roedores no laboratório. Mas não é apenas isto que os torna a ferramenta correta para o trabalho de pesquisa; esses animais, diferentes das pessoas, dos cães, dos demais animais de estimação, não são diversos entre si, não são heterogêneos, são geneticamente idênticos, como já havia dito a dr. ${ }^{a}$ Débora na conversa transcrita acima. Ora, tal fato, que torna os roedores tão preciosos e lhes confere um grande valor instrumental, não ocorre espontaneamente, é fruto de labor feito nos biotérios e laboratórios, de cruzar intencionalmente gerações e gerações de irmãos, para a obtenção de animais homogêneos geneticamente. Ou seja, os animais foram transformados no e pelo trabalho do laboratório, antes de se tornarem o que 
são hoje: uma ferramenta à disposição de pesquisadores que precisam de um material homogêneo para testar "uma enzima, uma molécula, um gene", como afirmou a dr. ${ }^{a}$ Tereza. Se o laboratório, como define Knorr-Cetina (1999), não é apenas o lugar em que os experimentos ocorrem, mas um espaço em que a ordem natural é reconfigurada e os processos naturais são "trazidos para casa" a fim de serem submetidos a condições locais controladas, o camundongo, quando entra neste recinto, progressivamente se diferencia de seus semelhantes que vivem nos campos, nas ruas e nas casas. Eles são animais purificados, com linhagens bem demarcadas e homogeneidade genética.

Os roedores descendentes de linhagens purificadas e padronizadas são considerados virtualmente os mesmos, o que favorece a replicação dos experimentos e permite aos pesquisadores estudar a ação de químicos, radiação, vírus ou qualquer outro tipo de fator sobre os animais. Segundo Fujimura (1996), as linhagens de camundongos intercruzados materializaram os conceitos de herança e invariabilidade genética para cientistas, ou, "em outras palavras, as ideias de invariabilidade, homogeneidade e padronização se tornaram (arte) fatos reais de laboratório através do desenvolvimento de animais intercruzados" (Fujimura 1996: 30).

Por encarnarem materialmente a homogeneidade e a invariabilidade, os roedores são os animais experimentais mais utilizados nas pesquisas em ciências da vida (Smith, Birke e Sadler 1997; Higashijima, Takahashi e Kato 2009). Os camundongos são considerados o "padrão ouro" em termos de modelos animais na área biomédica e seu uso não requer justificativas ou explicações; ao invés disso, estes animais são um recurso usado em laboratórios para garantir a comparabilidade com experimentos (já realizados ou potencialmente realizáveis) levados a cabo em outros locais de pesquisa. Se hoje parece ser imperativo, para não dizer óbvio, o uso dos roedores em pesquisas sobre moléculas, enzimas ou genes no laboratório, em seu início nada havia de inequívoco. A criação do "padrão ouro" foi um acontecimento na ciência. Para Asdal (2008), se fôssemos compor a "grande narrativa" descrevendo a transformação da biomedicina em uma ciência fortemente experimental apoiada no uso de modelos animais - a ser comparada à grande narrativa feita por Foucault para o que se passou na medicina na primeira metade do século XIX -, esta seria escrita do seguinte modo: "enquanto no início do século XIX se dependia fundamentalmente do post mortem para a obtenção de conhecimento sobre a vida, no final do século XIX o post mortem foi (parcialmente) deslocado pelo exame do corpo vivo do animal" (Asdal 2008: 901-902). Mas, como a própria autora admite, a história não foi linear; com efeito, o uso intensivo do modelo animal em experimentos seguiu uma trajetória bem mais heterogênea do que a busca da "grande narrativa" pode nos levar a acreditar.

Quando começou a haver um uso mais intenso de animais em experimentos nas ciências biomédicas e biológicas, um número muito variado de espécies era 
empregado no trabalho científico: cães, rãs, cavalos, vacas, pombos, borboletas, tartarugas, vermes, entre outros (Asdal 2008). O camundongo ainda não havia se instalado plenamente no lugar que veio depois a ocupar, o de animal de laboratório preferencial. O deslocamento operado da diversidade em direção à unidade revela uma mudança na própria biologia, que passa a se orientar para uma concepção genética e molecular (Logan 2001).

O período entre 1900 e 1955 foi crucial no processo de conversão do camundongo em organismo padronizado para a pesquisa biomédica. Um dos locais fundamentais para compreendermos a história do seu desenvolvimento e "aperfeiçoamento" foi o Laboratório Jackson, situado em Bel Harbor, nos Estados Unidos. Esta instituição foi responsável por estabilizar linhagens genéticas purificadas e por produzir animais em larga escala, primeiro para uso local, depois para distribuição a outras instituições e, por fim, para comercialização. As linhagens começaram a ser purificadas como descrito pela dr. ${ }^{a}$ Tereza em sua fala, através de cruzamentos seguidos entre irmãos, por muitas e muitas gerações, até que os camundongos se transformassem, de acordo com C. C. Little, fundador da instituição, em "reagentes biológicos puros ao serviço de inúmeras linhas de pesquisa" (Rader 2004: 25). Esta concepção parece ser corrente no presente.

A padronização certamente conta como uma das principais qualidades dos camundongos para justificar a preferência formada em torno deles, mas há outras características que os tornam aptos a ocupar a posição de "padrão ouro" entre os modelos animais: são pequenos, relativamente domesticados, fáceis de manusear, não há muita dificuldade em manter suas condições de habitação e alimentação, sua reprodução é célere, eles podem padecer de várias doenças que acometem os humanos (câncer, doença cardíaca, diabetes, etc.).

Contudo, muitas destas qualidades só foram reconhecidas depois que os camundongos já estavam em uso. Portanto, não podemos atribuir a clara preferência por esse animal apenas a suas características intrínsecas - o que poderia conduzir à equivocada ideia de que eles são animais de algum modo predestinados ou vocacionados à função de cobaias. Nem mesmo é possível dizer que eles se tornaram o modelo animal padrão graças exclusivamente à reengenharia posta em curso pelos pesquisadores do laboratório para transformá-los na ferramenta correta para o trabalho do qual são encarregados. Acontecimentos externos ao lócus de realização de pesquisa também estão implicados na história da ascensão dos camundongos ao posto de "padrão ouro". Para Rader (2004) foi crucial para a ampla difusão do uso de camundongos na ciência a pouca atenção concedida aos roedores por ativistas em prol dos direitos dos animais. Quando se inicia a luta contra o vivisseccionismo, a preocupação maior era com a defesa dos cães e outros animais com os quais os humanos conviviam com alguma simpatia e intimidade; as demais espécies, como ratos e camundongos, não eram prioritárias para o movimento ao menos até a 
década de 50 do século passado (Rader 2004; Lederer 1992). Além disso, no caso específico analisado por Rader, a decisão tomada por Little de converter o laboratório em uma unidade de produção de animais para comercialização - o que facilitou a sua adoção em muitos outros locais de pesquisa - foi tomada no período da "grande depressão" nos Estados Unidos, quando a sobrevivência material do laboratório estava ameaçada devido à insolvência de seus patrocinadores. Antes da crise econômica, o laboratório era fundamentalmente uma instituição de pesquisa que distribuía animais em pequena escala para outros laboratórios com os quais estava associado, mas depois se torna efetivamente uma unidade fabril para a produção de animais para pesquisa (Rader 2004).

Uma vez que foram estabelecidas as primeiras linhagens padronizadas de camundongos, rapidamente foram encontrados usos alternativos para elas em contextos os mais diversos, a ponto de se converterem, como argumenta Shostak (2007), em objeto liminar que permite a troca e o diálogo entre disciplinas e instâncias diversas, como instituições de regulação de pesquisa em saúde, laboratórios, agências de avaliação de riscos ambientais, etc.

Como podemos entender essa concordância sobre o valor dos camundongos? Segundo Rader (2004), o amplo consenso que se formou em torno desse organismo se deve à capacidade mostrada por ele para mediar tensões, de um lado, entre sistemas naturais e tecnológicos, posto que ele é simultaneamente um organismo "natural" e um "instrumento padronizado" de pesquisa. Por isso, em sua fala a dr. ${ }^{a}$ Tereza reconhece que são organismos vivos dotados de sensibilidade e inteligência (em menor grau que os cães), ao mesmo tempo em que afirma que são como coisas, são homogêneos, são descartáveis e, tragicamente, sempre morrem ao final do experimento. De outro lado, o consenso também parece ser uma resposta às tensões envolvidas no experimento com sujeitos, pois o camundongo na pesquisa é posto no lugar do humano por sua semelhança genética com este, e ao mesmo tempo pode ser submetido a tratamentos e riscos que não seriam admissíveis para os humanos, por isso, diz Little, "os cães podem ser nossos melhores amigos, mas os camundongos são nossos melhores aliados na luta contra doenças" (citado em Rader 2004: 21 -22). Se a ciência é feita de traduções e substituições, o animal é aquele que ocupa o lugar análogo ao do humano, sem as limitações éticas impostos para a pesquisa com pessoas, como nos disse a dr. ${ }^{\mathrm{a}}$ Tereza em trecho citado anteriormente.

Há, é claro, as restrições éticas relativas ao uso de animais em pesquisa. No Brasil, vigora desde 2011 uma legislação que determina a criação de uma CEUA - Comissão de Ética no Uso de Animais - em qualquer instituição que crie ou utilize animais em investigações científicas. A tramitação da lei que regula o uso de animais em pesquisa foi lenta - demoraram 13 anos até que a lei ganhasse a sua forma final e fosse aprovada pelo poder legislativo - por conta das difíceis negociações entre cientistas e ativistas dos direitos animais. O papel ativo desempenhado nessa instância pela militância em favor dos 
animais não se fez acompanhar, no Brasil, de outras estratégias como a de agressão e ameaça a cientistas e instituições, exceto em algumas poucas ocasiões (Machado e Filipecki 2011). A lei procura estabelecer novos padrões de manejo e uso, mas não desestabiliza a produção e utilização de animais em pesquisa.

Que os animais estejam bem estabilizados, padronizados como linhagens e tenham se tornado o "padrão ouro" em estudos biomédicos reduz a dificuldade no momento da escolha do modelo animal, mas não reduz a complexidade das práticas para seu ordenamento e manuseio. O biotério é uma unidade de produção de animais e materiais biológicos e é com frequência um ponto de passagem no início de uma trajetória como pesquisador em biomedicina. Alguns preferem se esquivar dele e procuram outros caminhos de inserção na carreira, como a dr. ${ }^{a}$ Beatriz, interlocutora na conversa apresentada acima, mas boa parte dos que estão na instituição em que esta pesquisa foi feita, ao menos durante a iniciação científica, mestrado e doutorado, acumula horas de trabalho com animais no biotério. Apenas quando o pesquisador adquire alguma senioridade e passa a ter seus próprios orientandos ele pode se dedicar a outras tarefas e deixar o trato com os animais para os iniciantes, como disse a dr. ${ }^{a}$ Débora. Vamos então conhecer brevemente como se organiza o biotério.

\section{O BIOTÉRIO}

A porta de entrada do prédio onde funciona o biotério dá para um amplo galpão, em cujo centro está uma grande máquina. Saem dela largos tubos que se dirigem ao teto, semelhantes a chaminés. À primeira vista, o lugar lembra uma unidade fabril. Entretanto, aquele equipamento nada produz, é uma máquina na qual são higienizadas as caixas em que vivem os animais - ratos, hamsters e camundongos.

Na parede do lado esquerdo da entrada se vê um painel contendo tabelas, quadros de informações, escalas de horário de trabalho, de lavagem de uniformes, número de animais solicitados pelos diferentes laboratórios, etc. Sua moldura é formada por fotos ternas e graciosas de filhotes de camundongos com olhos fechados, dormindo uns sobre os outros. Ao ver as fotos, me ocorreu também que, neste recinto, talvez os animais não sejam apenas "coisas" ou "material descartável".

Os animais residem em duas alas separadas, uma à direita e a outra à esquerda do galpão central. Nos recintos onde camundongos, ratos e hamsters vivem a temperatura é mantida continuamente a 21 graus, a preferida pelos moradores, e a umidade do ar também é controlada por um sistema computadorizado. A ala da direita é local de reprodução dos animais e sua moradia até que chegue o momento em que começam a participar nas pesquisas. Eles nascem aí, onde são cuidados por técnicos e permanecem usualmente até a 
idade de três meses. As habitações dos animais ficam em salas com portas que possuem janelas de vidro, para que eles sejam vistos sem que haja necessidade de contatarem diretamente com pessoas.

Em cada cômodo há muitas gaiolas empilhadas umas sobre as outras, similares a prédios altos. Cada caixa transparente, forrada com cama de serragem, contendo dois a cinco animais, se acopla a uma estrutura metálica. Esta armação é parte do sistema de ventilação que troca o ar das gaiolas a cada minuto; assim, embora as caixas normalmente sejam substituídas semanalmente, os animais jamais sentem cheiros de excrementos. Na parte superior de cada uma das unidades são colocadas água e comida, e esta deve ter a textura apropriada para provocar algum grau de desgaste nas presas dos roedores e não deixá-las crescer excessivamente. Em algumas das caixas são postos brinquedos, pequenas bolas de papel. De acordo com as normas do local, o bom cuidado não se limita a oferecer comida, bebida e habitação apropriadas, inclui também uma preocupação com o bem-estar psicológico dos animais, por isso foram introduzidos elementos lúdicos: as bolinhas de papel. Segundo o responsável pelo biotério, tédio e ansiedade são afecções das quais os animais não são poupados. Técnicos e cuidadores do biotério identificam facilmente seus sinais ao observarem falhas na pelagem do rosto, resultado de uma repetição excessiva do gesto comum de coçar a face. Esta observação sobre as aflições dos animais não é apenas um modo local de interpretar determinados comportamentos estereotipados dos animais; considerações sobre disposições afetivas e sobre os modos de lidar com elas são encontradas na literatura sobre a boa prática de cuidados com os animais experimentais (Davies 2010).

Se no biotério há uma luta para evitar o "tédio" e a "ansiedade", a batalha travada para impedir a entrada de agentes patológicos, contaminaçóes e o aparecimento de doenças envolve muito mais esforço e diligência. Os humanos que entram no recinto precisam usar gorro, capa, máscara, cobertura para os sapatos e luvas descartáveis para impedir que elementos perigosos à saúde dos animais sejam trazidos ao interior do biotério. Por isso também a ênfase na transparência das gaiolas e janelas de vidro, pois é importante saber o que acontece nas caixas e ao mesmo tempo minimizar o contato com os humanos. Estes são uma ameaça potencial, pois atuam como vetores de contaminação para os roedores.

Os animais saem desta primeira ala quando são requisitados para algum experimento. $\mathrm{Na}$ parte em que permanecem os animais "em uso" encontramos a mesma temperatura e umidade do ar; também há salas com inúmeras gaiolas, além de espaços destinados à manipulação de animais. Aí, as caixas recebem etiquetas que identificam o laboratório, a pesquisa, indicam datas e algumas características dos animais. A quase totalidade dos camundongos é da raça balbi - são pequenos, brancos, com olhos vermelhos e vivos. Em uma das salas para experimentos há uma esteira, semelhante às usadas em academias de 
ginástica, mas de menor comprimento. Adiante falaremos dela. Há, em outra sala, um equipamento onde são feitas outras intervenções nos animais, como as cirurgias e dissecações.

Os animais usualmente chegam saudáveis na ala de experimentação (exceto os diabéticos selecionados geneticamente) e só aí eles são levados a adquirir alguma enfermidade específica (asma, doença de Chagas, enfisema pulmonar, etc.). As pesquisas usualmente visam caracterizar as consequências de uma determinada condição sobre órgãos vitais - por exemplo, quais são os efeitos da obesidade no tecido hepático ou na estrutura óssea - ou testar algum tratamento, medicamento ou intervenção em animais adoecidos. Por fim, o destino final: o sacrifício. $\mathrm{O}$ desfecho de um experimento sempre envolve a morte do animal. Na maior parte das vezes isso acontece porque, para a conclusão do trabalho de pesquisa, não basta a descrição de resultados clínicos positivos obtidos pelo pesquisador. É preciso acrescentar outras provas para sustentar a conclusão de uma investigação. Via de regra, são usadas como evidências amostras de tecidos retiradas do corpo do animal, fragmentos que serão depois preparados, corados, fotografados, congelados e constarão dos relatórios e artigos escritos pelos pesquisadores. Isso exige que o animal, mesmo recuperado de uma doença grave, pereça. Ainda quando isto não é requerido, me disse Tiago, o responsável pelo biotério, o que fazer com o animal ao final da pesquisa? Neste biotério, os roedores não são reutilizados, assim só lhes resta como destino o sacrifício. O próprio Tiago admite que, embora esta seja uma tarefa corriqueira, nunca é feita por ele sem pesar.

\section{SACRIFÍCIO E MANUSEIO DE ANIMAIS}

Para alguns dos responsáveis por experimentos, a realização de procedimentos que ferem, causam doença e dor parece não ser tão problemática quanto o sacrifício. Há indícios deste fato na conversa com as pesquisadoras que relatei anteriormente; por exemplo, a dr. ${ }^{\text {a }}$ Beatriz nunca suportou a ideia de matar os animais - ela não mencionou os vários sofrimentos envolvidos nos experimentos - e também a dr. ${ }^{a}$ Débora falou em sacrificar os animais. Urânia, mestranda que faz pesquisa na área de dor, nos diz:

"Urânia: [...] eu acho que eu venho desmistificando um pouco isso [o uso de camundongos], principalmente trabalhando com dor, né? [...] procuro ver o que ele [o camundongo] 'tá sentindo, até onde o que ele sente é reflexo e o que realmente é dor, mas uma coisa assim que ainda é p'ra mim difícil, assim, de aceitar completamente é a ideia de sacrificar os animais, né? Você faz o experimento com 20 animais - usei, não vou usar mais para nada, aí sacrifico. Faz o deslocamento cervical, então, você segura o rabinho, puxa a cabeça, aí interrompe a ligação com o bulbo, que é onde fica o centro 
da respiração, aí ele morre rapidinho. [...] A gente estuda a dor, então a gente provoca a dor no animal p'ra estudar, né, então injeta ácido acético na cavidade abdominal e ele vai demonstrar um comportamento de dor [...] Eu tenho assim simpatia pelo vegetarianismo, não matar animais p'ra comer [...], então, sabe, eu ainda não digeri por completo esse fato de ter que sacrificar animais, né, são 20, 30, 15 ratos, camundongos, e aí o que eu penso, e me dá uma certa força, é pensar que tem um objetivo maior, que vai salvar algumas vidas ou ajudar, né, no conforto de algumas pessoas no futuro, mas é uma coisa que me incomoda."

Faz parte da pesquisa de Urânia produzir dor. Em seu aprendizado ela desenvolveu a sensibilidade e a habilidade para discernir, a partir das reações dos animais, aqueles comportamentos que expressam dor e não mero reflexo. Sua maior dificuldade permanece, entretanto, a realização do sacrifício. Sá, Medeiros e Schirmann (2011) também encontraram, em seu estudo sobre relações de humanos com cobaias em um laboratório, o mesmo sentimento de pesar vinculado mais à realização do sacrifício do que ao ato de infligir um sofrimento ao animal, quando tal ato é uma exigência do protocolo experimental. Para eles o blues relacionado à morte do animal é amenizado quando há resultados e uma produção que legitima aquele sofrimento como algo válido.

O sacrifício é, para Lynch (1988), um dos aspectos centrais no trabalho com animais em laboratório. De acordo com ele, há um conjunto de práticas que realizam a passagem do "animal naturalístico", um organismo vivo e completo, para o "animal analítico", cujas partes do corpo são transformadas em artefatos de laboratório, como lâminas contendo material biológico, e, portanto, convertidas em dados. Este processo é descrito por ele como a realização de rituais de purificação. Além disso, a recorrência do termo sacrifício nas falas de pesquisadores aponta, segundo Lynch, para a existência de um discurso sacralizador, em um duplo sentido. O primeiro e mais óbvio é que o animal é imolado em nome de interesses mais elevados, a cura de doenças ou o avanço da ciência, como vimos no fragmento da entrevista com Urânia. O segundo sentido envolve a conversão do animal em objeto sagrado de investigação técnica na cosmologia científica. Mas, ao examinar essa questão, Lynch estava pouco interessado nos animais e nas suas relações com os humanos, sua preocupação era com o processo de produção de conhecimento e o lugar central que o sacrifício representa nesta construção.

Sendo, ao contrário, esta a preocupação aqui, retomo o início da fala de Urânia: "venho desmistificando..." O que ela pode querer dizer com isso? Outros relatos podem nos fazer supor que ela está se tornando habituada aos animais, assim como estes também devem se habituar aos humanos no laboratório. Ela está sendo transformada pela experiência de lidar com camundongos e ratos, algo que neste contexto faz parte do que é "tornar-se cientista". 
A própria Urânia conta como foi o seu começo:

"Urânia: Eu fiz um curso aqui de manipulação de animais, foi aí que eu tive o primeiro contato, mas foi curtinho, né? Aí a minha orientadora pediu os animais para a gente fazer o experimento e eu fui manipular com ela, então ela pegava, botava a mão na caixa, pegava o animal e eu ficava, né, com medo de ele me morder, com receio, eu tava com mais medo do animal do que ele de mim, né, e aí fui manipulando, fui pegando o jeito assim com um, dois dias eu pegava já [...], aí tinha que segurar ele pela patinha, aplicar a injeção, então no começo eu segurava os animais morrendo de medo, depois eu peguei o jeito."

Pode parecer bastante óbvio, mas tocar um camundongo, executar uma série de procedimentos com eles, como ensinar a correr em uma esteira ergométrica, dar injeção, fazer uma cirurgia, não fazem parte do repertório de gestos que usualmente dirigimos a animais. Para ser um bom pesquisador/experimentador, ao menos em seu estágio inicial, não basta a habilidade para lidar com o "animal analítico", é preciso disposição e aprendizado para lidar com o "animal natural”, cuja mordida tememos, e saber fazer coisas com ele.

"Danilo: A primeira vez que eu fui injetar um camundongo, eu matei ele na minha mão de tanto nervosismo, eu peguei o camundongo, fui injetar no peritônio com a técnica do meu lado me ensinando na primeira vez. [...] Foi uma tremedeira tão grande que eu injetei a agulha tremendo e ele morreu em minha mão, eu acho que dilacerei todos os órgãos dele ali. Aí eu disse para técnica, você já me ensinou, agora me arruma aí uns camundongos e me deixa quietinho treinando, aí eu fiquei quietinho, só eu e os camundongos... [...] Aí eu fiquei tentando pegar ele firme e injetar, aí eu chegava com a agulha e dizia para mim: oh, tem que parar com o nervosismo. Acabei sozinho aprendendo, eu nunca mais errei, foi só a primeira vez que me traumatizou tanto..."

Quando Gabriela, que tinha formação em botânica, teve a sua primeira conversa com a coordenadora do laboratório, esta perguntou a ela: "Você não tem medo de rato, não é?" Ela respondeu que não. Ela me diz, depois de narrar o diálogo com a coordenadora:

"Gabriela: Hoje eu trato com camundongo como uma coisa, que é algo que nunca imaginei que fosse fazer, né? Eu faço sacrifícios, eu não imaginei que ia fazer isso sem dar muita importância, tudo bem que antes eu matava a plantinha, mas ela não tinha nenhum movimento, né?" 
Um dos sentidos de tratar o animal como "coisa" parece ser sacrificá-lo sem pesar, ganhar indiferença com relação ao fato de que ele é sensível e movente. Estar acostumado ao animal significa ser capaz de manuseá-lo com destreza e de pôr fim à sua vida ao final do experimento. Mas estar familiarizado com eles, saber as manobras necessárias ao seu manejo não garante que a convivência será sempre pacífica e que os animais atuarão do modo como se espera.

"Diana: Porque a pesquisa é uma coisa muito ingrata, um dia dá tudo certo, no outro dia você faz o trabalho e dá tudo errado [...] Sabe o que é você fazer o experimento nas mesmas condições que você fez na semana anterior e não funcionar nada? Mas são vários fatores que influenciam, por exemplo, o animal, se 'tava estressado, se mudaram a ração do animal, pode ser que esse experimento dê um resultado diferente [...]."

"Paulo: A nossa pesquisa é pesquisa de aplicação, é prática, então às vezes acontece da infecção não 'tar no dia correto, ou a gente esperava que o parasita estivesse num estágio avançado no animal, mas não avançou. Mas a gente vai contornando, né."

Os animais não apenas se estressam com alterações em seu meio, ou, como mencionado antes, se entediam com a falta de estímulos, advinda da vida de rotinas quase inalteráveis, ou, ainda, resistem mais à infecção do que era esperado; há outros acontecimentos inesperados, nem todos eles com consequências negativas:

"Aconteceu um episódio lá no laboratório muito interessante. Então eles [pesquisadores] estudavam uma determinada proteína na linhagem de camundongo balbi. Só que faltou o balbi e eles queriam fazer o experimento de todo jeito. [...] Aí um aluno chegou p'ra o orientador e disse: só tem asnel. Aí ele disse: traz esse asnel mesmo. Então eles pegaram esse asnel e imunizaram. [...] Com balbi estava dando algum resultado, eles conseguiam cinquenta por cento de sobrevivência. [...]. Eles pegaram esse asnel e fizeram a mesma coisa, aí teve uma sobrevivência de 70 a 80 por cento" [fragmento de entrevista citado em Almeida (2009: 77)].

Os animais podem surpreender e responder de modo diverso ao que é feito com eles quando entram em algum protocolo de pesquisa em que são medidos, pesados, treinados, adoecidos, tratados, manuseados de diferentes formas. Um dos tipos de manipulação de animais mais comum no laboratório é a realização de cirurgias com os camundongos para a extração de órgãos e tecidos a serem depois transformados em lâminas, para esquadrinhamento no microscópio, produção de imagens, etc. Há todo um conjunto de materiais requeridos para isso. Sandro, doutorando do laboratório, descreve esse tipo de procedimento: 
"Sandro: Se eu vou fazer uma cirurgia num animal, bom, fecho os olhos e digo: vou precisar anestesiar o animal, então eu preciso do anestésico tal, então eu vou pegando e colocando junto de mim, vou precisar de seringa e agulha para injetar, vou abrir o animal, tesoura tal, pinça tal, vou precisar coletar sangue, então vou pegar uma pipeta, vou pegar uma pera, vou colocando tudo ali ordenadamente no ponto onde vou trabalhar, não 'tou nem com o animal ali na mesa ainda, mas faço todo o procedimento, vou suturar, vou precisar de fio de sutura, vou tirar órgão, vou precisar fixar, então vou ter que ter fixador, formol, vou pegar isso, vou congelar, vou botar isso em gelo..."

Este exemplo não mostra apenas um dos procedimentos comuns no biotério, indica também que o animal é um componente de um dispositivo experimental bem mais complexo. Há as cirurgias feitas nos animais - e todas as ferramentas necessárias. Estas poderiam ser destinadas, por exemplo, a injetar células-tronco via a artéria caudal do animal, a fim de avaliar seus efeitos, algum tempo depois, sobre o coração chagásico. Para comprovar os efeitos do experimento, será preciso nova intervenção. Neste caso, além dos materiais usuais nas cirurgias, são requeridos fixadores, lâminas, corantes, que se conectam ao sofisticado microscópio e a uma máquina fotográfica ultrapotente que registrará as imagens dos tecidos cardíacos. Além disso, o material biológico será congelado e mantido etiquetado e identificado em um freezer e poderá ser revisto em qualquer momento. As intervenções serão realizadas em um equipamento que impede a troca de ar entre o espaço de manuseio do animal e o exterior, e este aparelho soma-se a outros procedimentos protocolados para minimizar ou impedir contaminações no meio e no material coletado.

As entidades experimentais no laboratório são submetidas a um sistema experimental envolvendo um arranjo de coisas, procedimentos, habilidades que no laboratório tem como objetivo responder às perguntas feitas pelo experimentador, que, por sua vez, devem se converter em enunciados aceitos por outros (Rheinberger 1997). Justamente o que singulariza a ciência em relação a outras práticas que envolvem a produção de assertivas e persuasão é que suas estratégias de convencimento dependem, em larga medida, da materialização das provas, da realização de procedimentos, da fabricação de inscrições que visam garantir a realidade dos resultados obtidos experimentalmente. O experimento confere ao experimentador o direito de falar em nome das coisas, ele é sua fonte de autoridade (Stengers 2002).

Assim, quanto mais elementos o cientista agrega ao seu dispositivo experimental - algo que pode diferenciar um laboratório de outro e mostrar a superioridade das provas obtidas aí -, mais chances ele terá de fazer valer seus enunciados. Diana, bolsista de pós-doutorado, por exemplo, conseguiu responder à questão posta em seu trabalho de doutorado graças a um componente diferencial do laboratório: o camundongo fluorescente. 
"Diana: Utilizei os camundongos que tem aqui, transgênicos da proteína GSP, que a gente não tinha em São Paulo, então consegui responder algumas perguntas que não tinha como responder no outro laboratório. [...] Todas as células desse camundongo são fluorescentes verdes. Então a gente pegou algumas células do sistema imune dele. Depois a gente pegou um animal que não é verde, irradiou o animal e matou todas as células do sistema imune dele. Aí injetamos as células do sistema imune do animalzinho verde, então todas essas células do sistema imune desse animal, que era selvagem, agora são verdes. [...] Com microscopia de fluorescência (o sistema de microscopia de fluorescência daqui é fantástico, acho que não tem outro tão bom no Brasil), a gente podia acompanhar essas células no animal, então a gente injetava o tumor e via que essas células verdes iam atrás do tumor e depois com o tratamento da enzima a gente aumentava o número de células verdes que iam atrás do tumor. A gente achava que a inibição do crescimento do tumor estava correlacionada, né, com a enzima que estimularia o sistema imune p'ra combater o tumor. Isso eu não podia fazer lá [em São Paulo] porque não tinha esses camundongos."

Os camundongos fluorescentes, associados aos camundongos "selvagens" (não verdes), ao equipamento de irradiação, ao microscópio de fluorescência e a outros componentes do dispositivo laboratorial permitiram a Diana propor questões para as quais as respostas não poderiam ser encontradas no laboratório ao qual ela estava antes filiada. Particularmente os animais transgênicos e a aparelhagem de microscopia conferiram ao laboratório um caráter distintivo, uma vez que lá se podem obter provas diferenciadas, capazes de sustentar um enunciado acerca das propriedades imunomoduladoras e antitumorais de uma substância.

Recentemente foi incorporado ao aparato instrumental um novo equipamento, um aparelho para a realização de ecocardiogramas em camundongos. Este equipamento também confere uma posição de vantagem ao laboratório. Qual o "diferencial" obtido com a aquisição deste equipamento? Nina, pesquisadora que opera o aparelho, nos explica o ganho obtido com ele. Anteriormente, ela trabalhava com terapia genética para cardiopatia, usando o rato como modelo experimental. Ela acompanhava o que acontecia com o coração de seus animais usando equipamento para ecocardiogramas feito para humanos. O coração do camundongo, entretanto, é menor e mais rápido que o do rato, o que impede a sua visualização com um aparelho convencional; assim, a verificação e o acompanhamento dos resultados do tratamento com células-tronco, até então, implicava na necessidade da realização de transplantes em um número maior de animais, muito próximos geneticamente, cada um dos quais era sacrificado após determinado intervalo de tempo, para que fosse estabelecida uma série temporal de avaliações. Mas o uso do equipamento 
apropriado, que "tem uma potência muito maior, permite que a gente tenha imagens assim como se fosse um coração de humano...", como disse Nina. Continua ela:

“Nina: Então o equipamento é novo, [...] e eles querem ver como está o coraçãozinho desses camundongos... A gente anestesia e faz o exame por fora, né, que a pesquisa experimental é muito invasiva; para ver, o jeito é matar o bichinho, abrir e olhar o coração... Com esse equipamento você pode fazer isso sem abrir o animal, que se mantém vivo, e você vai acompanhando ele ao longo do tempo como se fosse um ser humano mesmo... [...] É um trabalho novo, né? Ninguém tinha feito isso, esse equipamento é único em toda América Latina. [...] Esse aqui é só para camundongos e ratos, nem é p'ra humanos. A diferença é a seguinte: o nosso coração bate em média 70 batimentos por minuto, o ratinho em torno de 250 por minuto, o camundongo 650 por minuto, então a velocidade é imensa, num pedacinho assim do tamanho da minha pontinha de dedo, então é muito pequeno... Precisa ter um equipamento que consiga ver toda a parte interna desse coração pequeno que 'tá batendo 600 vezes por minuto, então esse equipamento é muito bom..."

Com esse novo equipamento é possível obter provas, que não seriam alcançáveis de outro modo, devido às especificidades do coração do camundongo, seu ritmo e tamanho. Mas justamente por se ajustar ao que é próprio ao animal é que, como diz Nina, é possível ver o seu coração e acompanhar os desdobramentos do tratamento como se faz com humanos, sem que a série temporal das imagens dependa do sacrifício de uma série de animais "idênticos". A consideração da diferença do corpo do camundongo, tornada possível pelo aparelho, permite que ele seja visto como se fosse humano.

Como vimos, os camundongos no laboratório são animais altamente selecionados, especificados em suas linhagens e variedades; os modelos animais com doenças importantes para os humanos são resultado de custosos esforços para sua produção. Eles são recursos bastante valiosos para o laboratório, por isso, na maior parte das vezes, os experimentos são realizados inicialmente in vitro e apenas quando os primeiros resultados autorizam é que se inicia a fase de teste in vivo. O animal é um recurso a ser usado com parcimônia. Sua obtenção envolve a obediência a uma sequência de ações. Antes de seu início, é necessário que o projeto seja examinado pelo CEUA, que avalia se os procedimentos propostos são apropriados. Esta apreciação consiste em um julgamento acerca da quantidade de animais que se pretende utilizar - a demanda é excessiva ou adequada? Aliás, o responsável pelo biotério me informou, com satisfação, que, nos últimos anos, o rigor na avaliação do número de animais necessários à pesquisa conduziu a um decréscimo significativo na produção de 
camundongos e ratos naquela instituição. Além disso, a qualidade científica da investigação também é levada em conta - o protocolo é claro e bem formulado? Ele permite responder às perguntas colocadas pela pesquisa? Caso as respostas a estas questões sejam negativas, a autorização para a realização da investigação não é concedida - ao menos temporariamente, até que eventuais pendências sejam resolvidas -, pois não se pode conceder licença para usar e sacrificar animais se a pesquisa não é bem avaliada do ponto de vista técnico e científico.

Quando o projeto é aprovado pela CEUA, uma solicitação é feita ao biotério para que providencie a entrega do lote de animais requisitado. Só então começa uma questão prática fundamental: como obter os animais doentes e como lidar com eles?

\section{LIDANDO COM OS MODELOS DE DOENÇA}

Usualmente o animal aparece como "modelo" para a compreensão de processos biológicos ou para a antecipação das consequências de determinados procedimentos (administração de drogas, realização de tratamentos, etc.) em humanos. Mas falar de modelos em ciência não significa apenas dizer que estes são representações cognitivas, eles são também encarnações de ações e práticas que constituem tipos de questões científicas e indicam que perguntas podem ser respondidas (Friese 2009). Segundo Birke (2003), o modelo animal é desnaturalizado e abstrato, pois é um "organismo artificial" e um instrumento destinado a fazer a "natureza" falar. Mas como essa entidade abstrata e desnaturalizada é manejada na prática pelas mãos de humanos - pesquisadores e técnicos - aos quais eles podem morder, dos quais eles podem querer fugir? E como o animal abstrato emerge do animal vivo, reativo e em movimento no laboratório?

No laboratório, a maioria das pesquisas está voltada para a produção de conhecimento que em última instância beneficiará humanos. Se os camundongos são os substitutos destes na experimentação de tratamentos com células-tronco ou outros medicamentos, é imprescindível que os animais sofram das mesmas doenças das quais os humanos padecem. Mas, se os animais chegam aos experimentos sem qualquer enfermidade, a produção de modelos com doenças específicas é uma das primeiras tarefas a serem executadas nas investigações que envolvem o uso de animais. Como isso é feito?

Vejamos como se produz hipertrofia cardíaca:

"Nina: Eu trabalhei com hipertrofia do coração, então eu [a] induzia no ratinho, colocava um anelzinho na saída da aorta quando o ratinho era bebezinho, o anel ficava folgado, na medida em que o animal ia crescendo o anel começava a apertar a artéria e o coração, p'ra jogar o sangue fora 
tinha que fazer muito mais força porque o sangue tinha de passar por um lugarzinho estreito e isso acaba aumentando o coração de tamanho. É parecido com as doenças que tem em humanos, então a gente imitava no rato a mesma coisa que acontece no humano."

Em outro caso, Eduardo, bolsista de iniciação, ao apresentar seu trabalho na sessão científica do laboratório, conta a labuta para a produção do seu modelo animal de DPOC, doença pulmonar obstrutiva crônica. Depois de estabelecer a relevância da doença em humanos, ele abordou seu problema prático inicial: como produzir camundongos com DPOC? Como provar e exibir a sua realização? Isto se mostrou uma tarefa realmente complicada.

Primeiro foi preciso ensinar os camundongos a usarem a esteira ergométrica. Passado o período de aprendizado, o desempenho dos animais foi testado e mediu-se o tempo que levavam para atingir a exaustão. A medida é feita da seguinte forma: o camundongo é posto para andar em uma esteira com inclinação de 10 graus, cuja velocidade é aumentada em intervalos regulares de tempo, e o animal mostra que está exausto quando cai para trás da esteira; em seguida, estímulos - pequenos choques elétricos - são administrados ao camundongo, que, se ainda tiver alguma força, tornará a correr, mas, caso contrário, permanecerá deitado, mesmo recebendo os estímulos dolorosos.

Tendo registrado o desempenho dos animais, Eduardo administrou-lhes uma substância, esperou 21 dias e testou mais uma vez o desempenho deles. Desta feita, seu desempenho foi bem inferior ao que fora alcançado antes. Assim, estava provado clinicamente que os animais apresentavam sinais de doença pulmonar.

Mas isso não bastava, era necessário multiplicar as provas de que os animais sofriam realmente de DPOC. Para isso era preciso produzir amostras do tecido pulmonar, colocá-las em lâminas, colori-las e fotografá-las, para finalmente ter a prova definitiva. Isso não se mostrou nada fácil. Ele adotou o seguinte procedimento: prendeu algumas seringas à parede, verticalmente, e acoplou a sua ponta uma fina mangueira, que foi introduzida na traqueia dos animais, dos quais ele havia descartado a cabeça. Através das mangueiras gotejava um líquido que preenchia lentamente os pulmões dos camundongos (se o gotejamento fosse muito rápido, o tecido do pulmão poderia ser rompido). Depois de duas horas ele retirou tecido pulmonar, montou as lâminas, fotografou-as, mostrando o novo tamanho dos alvéolos (pois o que caracteriza a doença é o aumento dos alvéolos pulmonares). Para ele, o que exigiu mais delicadeza e precisão foi fazer a incisão para introduzir a mangueira sem dilacerar a sua pequena e frágil traqueia.

Durante a apresentação, ao descrever esses procedimentos, ele mostrou a foto das seringas em cuja parte inferior estavam acopladas as mangueiras. Ele disse que sob as colunas estavam camundongos pendentes, mas em seguida se 
corrigiu: "quer dizer, não todo o camundongo, uma parte deles já foi descartada”. A parte descartada dos camundongos era obviamente a cabeça, e ele os retirou da imagem porque tal visão poderia melindrar as pessoas. Uma pesquisadora que estava na audiência observa que viu os "bichinhos" sem cabeça, ela não se chocou e complementa: "essa é nossa vida, nós estamos acostumados com isso".

Esse exemplo nos mostra como a noção de modelo que por vezes aparece na literatura com um sentido abstrato, ou como uma realização pouco problemática, quando revelada nos seus detalhes práticos se mostra mais complexa. Construir o modelo requer habilidades de quem manuseia o animal, por exemplo, delicadeza ao fazer incisões para não destruir algo que já foi custoso produzir - como camundongos com DPOC comprovada em testes clínicos. Também é preciso familiaridade com o contexto de prática para não se abalar com os procedimentos aos quais é preciso submetê-los, como disse essa pessoa da audiência: ver animais sem cabeça não nos choca, pois essa é nossa vida, quer dizer, vida de cientistas.

\section{CONCLUSÃO}

A antropologia da vida se interessa pelos efeitos de nosso entrelaçamento com outros tipos de seres vivos, pelo que se produz nessa interseção entre os viventes. No contexto de prática observado, podemos dizer que, do mesmo modo que o animal de laboratório é feito no biotério pelos humanos - ele é concebido, homogeneizado geneticamente, protegido de enfermidades, afetado por doenças específicas sobre as quais se deseja conhecer algum aspecto, tecidos de seu corpo são retirados, coloridos, fotografados, guardados no freezer, etc. -, o pesquisador também é feito parcialmente pelos animais. Se tornar um cientista neste contexto é, em grande medida, aprender a tratar os camundongos como coisas, ser indiferente à visão de mutilados, tratá-los como objeto de curiosidade e como recurso disponível, mas também estabelecer com ele alguma forma de comunicação, de tal modo que seja possível reconhecer quando seu comportamento é um mero reflexo ou quando expressa dor, identificar em que situações a ansiedade dos animais confunde o resultado de um experimento, ensinar camundongos a usar a esteira ergométrica, etc. Ou seja, na situação experimental envolvendo humanos e camundongos - ou outros espécimes não se deve proceder como um "autista cosmológico" (Kohn 2007), se se deseja sucesso nos afazeres empreendidos em comum, ainda que em situação de assimetria.

Engajamento e distanciamento são dois momentos heterogêneos, que se alternam na mesma relação e, neste caso, um necessita do outro para que a pesquisa chegue a um bom termo. Segundo Holmberg (2011), o aprendizado do manuseio de roedores não corresponde a um processo em que há primeiro 
uma familiarização com os animais e os iniciantes se habituam a tocá-los, não temê-los, para em seguida aprenderem a reduzi-los a meros objetos através de procedimentos técnicos. Mesmo no contexto do laboratório, os pesquisadores são incitados a desenvolver um sentimento pelos animais, e isto não se deve a qualquer discurso superficial sobre o bem-estar do animal, sendo antes um requerimento para a boa prática de pesquisa, pois, no cuidado com o animal, todos os aspectos e variáveis do experimento devem ser levados em consideração. É importante observar que o cuidado com os animais envolve uma consideração daquilo que lhes é próprio, de suas especificidades, afecções e ações.

Com efeito, não há passividade de lado algum. O camundongo, embora possa ser tratado como uma qualquer ferramenta, é uma ferramenta singular de vários modos. Ele aprende a fazer coisas pouco usuais se os comparamos a seus semelhantes habitantes do mundo exterior ao biotério. Aprendem a correr em esteiras ergométricas, se estressam com mudanças em sua alimentação, se entediam ou sofrem crises de ansiedade, seus corpos resistem mais do que o esperado a infecções. Seu tamanho e a delicadeza de sua traqueia demandam um manuseio cuidadoso, o coração pequeno e célere exige um aparelho especial. Às vezes, é justamente por se considerar sua especificidade - caso do aparelho de ecocardiograma - que se consegue fazer com eles algo similar ao que é feito com os humanos; neste caso, recusa-se o procedimento mais invasivo que envolve o sacrifício de uma série de animais para investigar como seu coração responde para acompanhá-lo ao longo de um período de tempo mais longo, como se faz com os humanos que se tornam sujeitos de pesquisa. Pesquisadores e animais de pesquisa se fazem conjuntamente. Se é assim, não é mesmo possível estabelecer claramente os limites do humano e, consequentemente, tampouco é possível manter intacta a divisão entre natureza e cultura, pertencendo o animal inteiramente à primeira esfera, enquanto apenas o homem estaria situado no domínio do cultural. 


\section{BIBLIOGRAFIA}

AlmeIDA, Bethânia Araújo, 2009, De Jaleco Branco: A Prática Científica de Pós-Graduandos em Um Instituto de Pesquisas. Salvador da Bahia, Universidade Federal da Bahia, dissertação. ASDAL, Kristin, 2008, "Subjected to parliament: the laboratory of experimental medicine and the animal body", Social Studies of Science, 38 (6): 899-917.

BIRKE, Lynda, 2003, "Who - or what - are the rats (and mice) in the laboratory", Society and Animals, 11 (3): 207-224.

CREAGER, Angela, 2002, The Life of a Virus: Tobacco Mosaic Virus as an Experimental Model, 1930-1965. Chicago, The University of Chicago Press.

DAVIES, Gail, 2010, "Captivating behaviour: mouse models, experimental genetics and reductionist returns in the neurosciences", The Sociological Review, 58 (S1): 53-72.

DESPRET, Vinciane, 2008, "The becomings of subjectivity in animal worlds", Subjectivity, 23: 123-139.

EVANS-PRITCHARD, E. E., 1978, Bruxaria, Oráculos e Magia entre os Azande. Rio de Janeiro, Jorge Zahar Editor.

EVANS-PRITCHARD, E. E., 2007, Os Nuer. São Paulo, Perspectiva.

FRIESE, Carrie, 2009, "Models of cloning, models for the zoo: rethinking the sociological significance of cloned animals, BioSocieties, 4: 367-390.

FUjIMURA, Joan, 1996, Crafting Science: A Sociohistory of the Quest for Genetic Cancer. Cambridge, MA, Harvard University Press.

GEERTZ, Clifford, 1978, "Um jogo absorvente: notas sobre a briga de galos em Bali", em Clifford Geertz, A Interpretação das Culturas. Rio de Janeiro, Jorge Zahar Editor, 278-32 1. HARAWAY, Donna, 2011 , "A partilha do sofrimento", Horizontes Antropológicos, 35: 27-64.

HIGASHIJIMA, J., K. TAKAHASHI, e K. KATO, 2009, "Mouse model: what do Japanese life sciences researchers mean by this term?, Journal of Science Communication, 8 (1): 1-8.

HOLMBERG, Tora, 2011 , "Mortal love: care practices in animal experimentation", Feminist Theory, 12 (2): 147-163.

INGOLD, Tim, 2000, "From trust to domination: an alternative history of human-animal relations", em Tim Ingold, The Perception of the Enviroment: Essays in Livelihood, Dewlling and Skill. Nova Iorque, Routledge, 61-76.

KIRKSEY, S. Eben, e Stefan HELMREICH, 2010, “The emergency of multispecies ethnography", Cultural Anthropology, 25 (4): 545-576.

KNIGHT, John, 2005, Animals in Person: Cultural Perspectives on Human-Animal Intimacies. Oxford, Berg.

KNORR-CETINA, Karin, 1983, "New developments in science studies: the ethnographic challenge", Canadian Journal of Sociology, 8 (2): 153-177.

KNORR-CETINA, Karin, 1999, Epistemic Cultures: How the Sciences Make Knowledge. Cambridge, MA, Harvard University Press.

KOHLER, R.E, 1994, Lords of the Fly: Drosophila Genetics and the Experimental Life. Chicago, The University of Chicago Press.

KOHN, Eduardo, 2007, "How dogs dream: Amazonian natures and the politics of trans-species engagement", American Ethnologist, 34 (1): 3-24.

LANDECKER, Hannah, 2007, Culturing Life: How Cells Became Technologies. Cambridge, MA, Harvard University Press.

LATOUR, Bruno. 1999. Vida de Laboratório. Rio de Janeiro, Relume Dumará. 
LEDERER, Susan E, 1992, "Political animals: the shaping of biomedical research literature in twentieth-century America, Isis, 83: 61-79.

LÉVI-STRAUSS, Claude, 1975, Totemismo Hoje. Petrópolis, Vozes.

LOGAN, Cheryl A., 2001, "[A]re Norway rats... things?": diversity versus generality in the use of albino rats in experiments on development and sexuality', Journal of the History of Biology, 34 (2): 287-314.

LYNCH, Michael, 1988, "Sacrifice and the transformation of the animal into a scientific object: laboratory culture and ritual practices in the neuroscience", Social Studies of Science, 18: 265-289.

MACHADO, Carlos José Saldanha, e Ana Tereza Pinto FILIPECKI, 201 1, "Sócio-antropologia de um fenômeno tecno-científico-político transnacional: o uso de animais em experimentação científica e a realidade brasileira", Revista Brasileira de Ciência, Tecnologia e Sociedade, 2 (2): 58-99.

MULLIN, Molly, 1999, "Mirrors and windows: sociocultural studies of human-animal relationships”, Annual Review of Anthropology, 28: 201-224.

PICKERING, Andrew, 1995, The Mangle of Practice: Time, Agency and Science. Chicago, The University of Chicago Press.

PIGNARre, Phillipe, 2004, O Grande Segredo da Indústria Farmacêutica. Lisboa, Campo da Comunicação.

RADER, Karen, 2004, Making Mice: Standardizing Animals for American Biomedical Research, 1900-1955. Princeton, Princeton University Press.

REES, Amanda, 2007, "Reflections on the field: primatology, popular science and the politics of personhood”, Social Studies of Science, 37 (6): 881-907.

RHEINBERGER, Hans-Jorg, 1997, Toward a History of Epistemic Things: Synthesizing Proteins in the Test Tube. Stanford, Stanford University Press.

SÁ, Guilherme José da Silva, 2010, “Abraços de mono’: elos perdidos e encontros intersubjetivos em etnografia com primatólogos no Brasil”, Mana, 16 (1): 179-211.

SÁ, Guilherme José da Silva, Márcio Felipe Salles MEDEIROS, e Jonas Silva SCHIRMANN, 2011, "Experiência e descarte: dores humanas e não humanas em um laboratório de neurotoxidade e psicofarmacologia", Sociedade e Cultura, 14 (2): 427-434.

SHOSTAK, Sarah, 2007, "Translating at work: genetically modified mouse models and molecularization in the environmental health sciences", Science, Technology, and Human Values, 32: 315-338.

SMITH, Jane A., Lynda BIRKE, e Dawn SADLER, 1997, "Reporting animal use in scientific papers", Laboratory Animals, 31: 312-317.

SOUZA, Iara Maria de Almeida, 2011, "Células-tronco: considerações sobre o regime de verdade e o regime de esperança”, em Cristiane de Magalhães Porto, Antônio Marcos Pereira Brotas e Simone Terezinha Bortoliero, Diálogos entre Ciência e Divulgação Científica: Leituras Contemporâneas. Salvador, Edufba, 153-178.

STENGERS, Isabelle, 2002, A Invenção das Ciências Modernas. Rio de Janeiro, Editora 34. 